\title{
Grazing and soil carbon along a gradient of Alberta rangelands
}

\author{
DARCY C. HENDERSON, BEN H. ELLERT, AND M. ANNE NAETH
}

Authors are Graduate Student, Department of Renewable Resources, University of Alberta, 751 General Services Building, Edmonton, Alberta, Canada, T6G 2H1, Research Scientist, Land Resource Sciences, Agriculture and Agri-Food Canada, P.O.B. 3000, Lethbridge, Alberta, Canada, T1J 4BI, and Professor, Department of Renewable Resources, University of Alberta, 751 General Services Building, Edmonton, Alberta, Canada, T6G $2 \mathrm{HI}$.

Abstract

The regional scale response of soil carbon mass to long-term grazing exclusion was investigated in the Canadian Great Plains. Vegetation, litter, macro-organic matter and soil were sampled in paired grazed and ungrazed treatments from 9 independent locations along an environmental gradient in southern Alberta. Vegetation and litter carbon mass were greater on ungrazed treatments, but no consistent grazing effect was observed for macro-organic matter (roots, subsurface litter) or soil (fine particles $<2 \mathrm{~mm}$ ) carbon mass per equivalent soil mass. Soil carbon in mixed grass prairie was positively correlated with clay content, but no grazing effect could be detected when this subset $(n=7)$ was analyzed by ANCOVA. Comparison of multiple sites with a consistent sampling and reporting method revealed no general trend in the response of soil carbon to grazing. Current range management practices to maintain range types in good to poor condition appear to be consistent with maintaining the soil organic matter pool in the northern Great Plains.

Key Words: mixed grass prairie, equivalent soil mass, bulk density, clay, carbon sequestration

Livestock grazing influences the forage production, biological diversity and soil quality of native rangelands (Holechek et al. 1998). Soil organic matter is the single largest store of organic carbon in semiarid rangelands (Anderson 1995, Eswaran et al. 1995). Concern over industrial emissions of carbon dioxide $\left(\mathrm{CO}_{2}\right)$ into the atmosphere has stimulated much research into soil carbon sequestration to mitigate the potential for climate change (Lal et al. 1995, Bruce et al. 1999). Manipulating grazing patterns might be an option for increasing soil carbon in native rangelands (Allen-Diaz 1996), but evaluation requires quantitative evidence. Milchunas and Lauenroth (1993) found no consistent soil carbon response to grazing across a variety of tropical and temperate rangelands. This may have been too broad a scope, since regional ecosystems differ in their evolutionary history of, and thus response to, grazing (Milchunas et al. 1988). The scope of our research was to determine if a consistent soil carbon response to

This research was supported through a Matching Investment Initiative between Agriculture and Agri-Food Canada and the Greenhouse Emissions Management Consortium. Thanks to Drs. E.W. Bork and R.F. Grant and 2 anonymous reviewers for helpful comments and suggested changes to the original manuscript. Thanks also to B. Johnson, L. Kremnijk, C. Gilbertson, V. Merrick and B. Crowder for field and lab assistance.

Manuscript accepted 3 Sept. 03.

\section{Resumen}

En las Grandes Planicies Canadienses se investigó la respuesta, a escala regional, de la masa de carbón del suelo a la exclusión a largo plazo del apacentamiento. La vegetación, el mantillo, la macro materia orgánica (raíces y mantillo subterráneo)y el suelo se muestrearon en tratamientos apareados de apacentamiento y sin apacentamiento, el estudio se realizó en 9 localidades independientes a lo largo de un gradiente ambiental en el Sureste de Alberta. La masa de carbón de la vegetación y el mantillo fueron mayores en los tratamientos sin apacentar, pero no se observó un efecto consistente del apacentamiento sobre la masa de carbón de la macro materia orgánica (raíces y mantillo subterráneo) y del suelo (partículas finas $<2 \mathrm{~mm}$ ) por la masa equivalente de suelo. El carbón del suelo en la pradera mixta estuvo positivamete correlacionado con el contenido de arcilla, pero cuando este subgrupo $(n=7)$ se analizó por ANCOVA. no se pudo detectar un efecto del apacentamiento La comparación múltiple de sitios con un método muestreo y reporte consistente no reveló una tendencia general de la respuesta carbón del suelo al apacentamiento. Las prácticas actuales de manejo de pastizales para mantener los tipos de pastizal en condición buena a pobre parece ser consistentes con mantener la reserva de materia orgánica del suelo de las Grandes Planicies del Norte.

grazing exclusion occurs among temperate, continental rangelands in southern Alberta, Canada. Because a change in soil organic matter is most often attributed to a concomitant change in plant production, we tested for differences in both above and below ground carbon pools.

Inconsistent soil carbon responses to grazing in the northern Great Plains might be related to the limited scale of sampling and thus inference in previous research. Among quadrat variation was used to test for differences between a single grazed and ungrazed treatment by Dormaar and Willms (1990, 1998), Naeth et al. (1991), Dormaar et al. (1994) and Frank et al. (1995). Independent replicates of grazed and ungrazed treatments from the same landscape (within $100 \mathrm{~m}$ ) were used by Dormaar et al. (1989), Manley et al. (1995), Biondini et al. (1998) and Schuman et al. (1999). Only Bauer et al. (1987) and Stohlgren et al. (1999) used replicate pastures from non-adjacent sites representing a variety of soils. The high cost of replicating and sampling multiple pastures and still controlling for variation in soil, grazing regime and exclusion duration are barriers to "ideally" replicated grazing experiments (Brown and Waller 1986, Stroup et al. 1986). The small scale studies still offer potentially useful obser- 
vations for regional meta-analysis, but are otherwise pseudoreplicated for making inferences at the regional scale (Oksanen 2001). Our research compared adjacent grazed and long-term ungrazed treatments (blocked for local control) from multiple sites up to $500 \mathrm{~km}$ apart (independent replicates).

There is no standard technique for separating soil from non-soil particles, and this complicates comparison of soil organic matter pools among published studies. The soil organic matter itself can be separated into several physically distinct pools that reflect differences in decomposition state and turnover rate (Gregorich and Ellert 1993). Fine soil particles are often assumed to represent the oldest, most humified, and slowly decomposed portion of the soil organic matter pool, whereas coarse soil particles like roots and litter are both added and lost more quickly. The relative proportion of each soil organic matter pool also changes with depth, such that more labile soil organic matter occurs near the surface (Anderson and Paul 1984). We separated 2 soil organic matter fractions for data analysis, since short-term grazing exclusion may yield differences in a soil organic matter pool that turns over more rapidly than more stable pools. Although the overall direction of change below ground was difficult to predict given the variety of responses reported in the literature, we assumed treatment differences in more labile, coarse soil should be more readily detected near the surface than among more stable fine soil particle fractions at depth.

Another possibility for inconsistent soil carbon responses is the variety of sampling and reporting methods used. Soil carbon can be reported 3 ways: (1) concentration as either \% carbon or $\mathrm{g} \mathrm{kg}^{-1}$ (e.g., Dormaar et al. 1994, Stohlgren et al. 1999), (2) carbon mass per either soil volume or area per soil depth increment (e.g., Schuman et al. 1999, Wienhold et al. 2001), and (3) carbon mass per equivalent soil mass (e.g., Berg et al. 1997, Mikhailova et al. 2000). The latter 2 units allow spatial scaling up of results, but carbon mass per volume might be confounded because soil mass per volume (bulk density) is also affected by grazing treatment (Ellert and Bettany 1995). These analytical discrepancies may limit the value of previous research for use in meta- analysis (Osenberg et al. 1999). Our research made use of a single sampling method and all soil carbon data was reported per equivalent soil mass to adjust for bias in soil bulk density. We also tested this assumption by comparing the sampling depths required to achieve an equivalent soil mass to illustrate how grazing increases bulk density.

\section{Materials and Methods}

\section{Experimental Design and Site Descriptions}

A total of 9 blocks, each with a pair of grazed and ungrazed treatments (18 experimental units) were sampled during the summers of 1998 and 1999. These blocks were selected from the Range Production Monitoring Network established by Alberta Public Lands (Moisey and Adams 1999), to represent an environmental gradient of rangeland ecosystems in southern Alberta, Canada (Table 1, Fig. 1). At one extreme, blocks 1 and 2 were typical of high elevation, subhumid, foothill fescue prairie (Moss and Campbell 1947, Strong

Table 1. Characteristics of nine rangeland blocks and associated grazed and ungrazed treatments located between $49^{\circ}$ and $51^{\circ}$, and $110^{\circ}$ and $114^{\circ} \mathrm{W}$ in southern Alberta.

\begin{tabular}{|c|c|c|c|c|c|c|c|c|c|c|}
\hline Block & $\begin{array}{c}\text { Soil Texture } \\
\text { Type } \\
\text { and Order }\end{array}$ & Elev. & MAP & $\begin{array}{l}\text { Jul. } \\
\text { MT }\end{array}$ & $\begin{array}{l}\text { Jan. } \\
\text { MT }\end{array}$ & $\begin{array}{c}\text { Grazed } \\
\text { Regime } \\
1999\end{array}$ & $\begin{array}{c}\text { Grazed } \\
\text { Condition } \\
\mathrm{n}^{3}\end{array}$ & $\begin{array}{l}\text { Ungrazed } \\
\text { Duration }\end{array}$ & $\begin{array}{l}\text { Ungrazed } \\
\text { Area }\end{array}$ & $\begin{array}{l}\text { Subsample } \\
\text { Quadrats } \\
\text { (Cores) } \\
\text { per Unit }\end{array}$ \\
\hline & & $(\mathrm{m})$ & $(\mathrm{mm})$ & $\left({ }^{\circ} \mathrm{C}\right)^{2}$ & $\left({ }^{\circ} \mathrm{C}\right)^{2}$ & & & (years) & (ha) & \\
\hline \multirow[t]{2}{*}{1} & $\begin{array}{l}\text { Loam, Orthic } \\
\text { Black Chernozem }\end{array}$ & 1370 & 480 & 14.7 & -6.8 & May to Oct & good & 49 & 0.35 & $6(18)$ \\
\hline & & & & & & Continuous & & & & \\
\hline \multirow[t]{2}{*}{2} & Loam, Orthic & & & & & & & & & \\
\hline & Black Chernozem & 1370 & 480 & 14.7 & -6.8 & $\begin{array}{l}\text { May to Oct } \\
\text { Continuous }\end{array}$ & good & 49 & 0.35 & $6(18)$ \\
\hline \multirow[t]{2}{*}{3} & Loam, Orthic & & & & & & & & & \\
\hline & Dk Brown Chernozem & 1240 & 390 & 18.0 & -7.5 & $\begin{array}{l}\text { May to Oct } \\
\text { Continuous }\end{array}$ & fair & 29 & 128.00 & $3(9)$ \\
\hline \multirow[t]{2}{*}{4} & Sandy-Loam, Orthic & & & & & & & & & \\
\hline & Dk Brown Chernozem & 880 & 370 & 18.2 & -8.7 & $\begin{array}{l}\text { May to Oct } \\
\text { Continuous }\end{array}$ & poor & 20 & 0.18 & $4(12)$ \\
\hline \multirow[t]{2}{*}{5} & Sand, Rego & & & & & & & & & \\
\hline & Dk Brown Chernozem & 850 & 360 & 18.3 & -8.9 & $\begin{array}{l}\text { May to Oct } \\
\text { Continuous }\end{array}$ & poor-fair & 23 & 0.18 & $3(9)$ \\
\hline 6 & $\begin{array}{l}\text { Clay-Loam, Orthic } \\
\text { Brown Chernozem }\end{array}$ & 800 & 330 & 19.2 & -9.9 & $\begin{array}{l}\text { May to Oct } \\
\text { Continuous }\end{array}$ & fair & 20 & 0.18 & $3(9)$ \\
\hline 7 & Loam, Solonetzic Brown Chernozem & 940 & 350 & 19.3 & -11.4 & $\begin{array}{l}\text { May to Oct } \\
\text { Continuous }\end{array}$ & good & 50 & 64.00 & $6(18)$ \\
\hline 8 & Sandy-Loam, Orthic Brown Chernozem & 940 & 350 & 19.3 & -11.4 & $\begin{array}{l}\text { May to Oct } \\
\text { Continuous }\end{array}$ & good & 71 & 0.01 & $3(9)$ \\
\hline 9 & $\begin{array}{l}\text { Silt-Loam, Orthic } \\
\text { Brown Chernozem }\end{array}$ & 930 & 350 & 19.3 & -11.4 & $\begin{array}{l}\text { Nov to Apr } \\
\text { Continuous }\end{array}$ & good & 71 & 0.01 & $3(9)$ \\
\hline
\end{tabular}

Based on Agricultural Region of Alberta Soil Information Database (AGRASID 1998), and field descriptions classified according to the Agriculture Canada Expert Committee on Soil Survey (1987).

'Based on Environment Canada (1996) data for 1961-1990 at each site, or interpolated from adjacent sites by simple distance weighted averaging (MAP = Mean Annual Precipitation; MT = Mean Temperature).

${ }^{3}$ Based on method described by Wroe et al. (1988) and reported in Moisey and Adams (1999). 


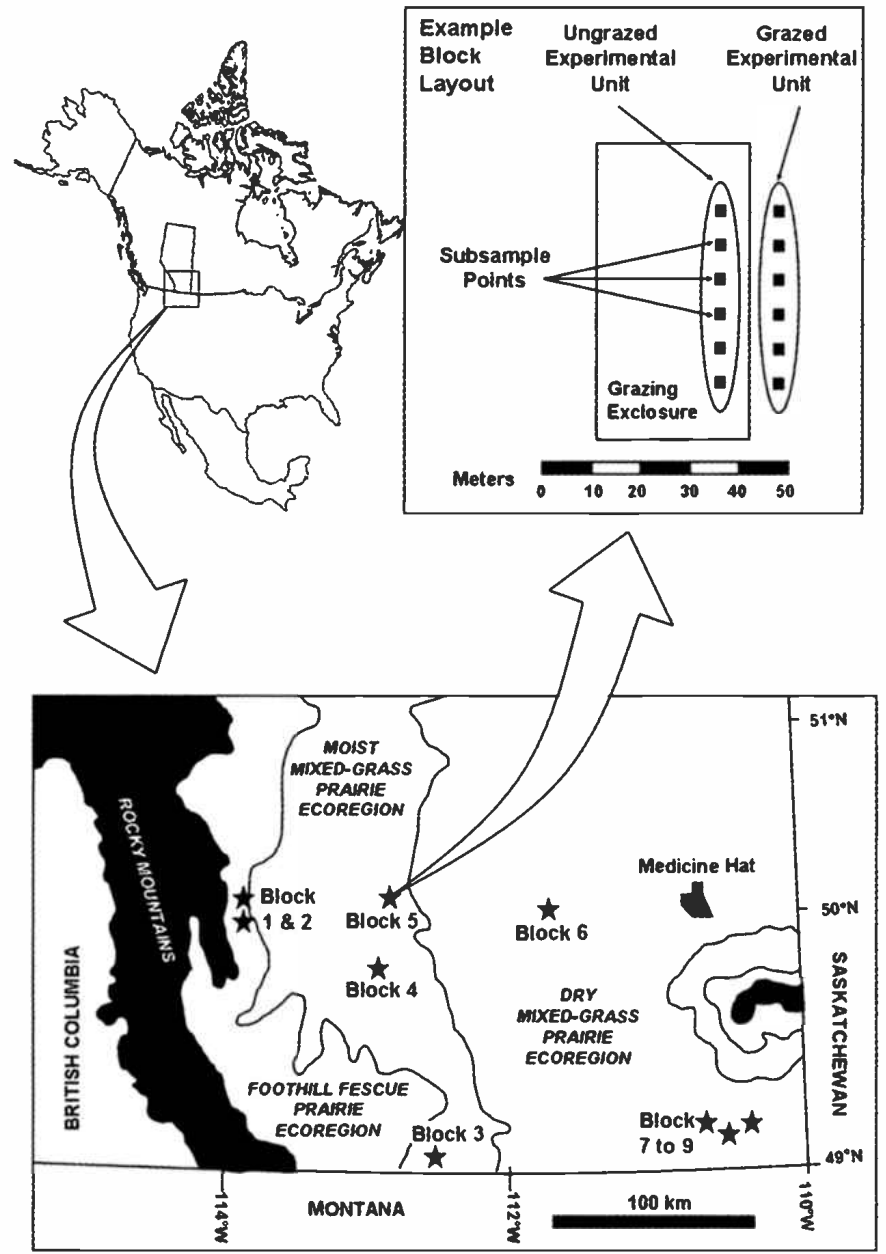

Fig. 1. Locations of the 9 blocks sampled in southern Alberta, Canada and an example block and subsample layout.

and Leggat 1991), and at the other extreme blocks 6 to 9 were typical of low elevation, semiarid, northern mixed grass prairie (Coupland 1950, Strong and Leggat 1991). Soils also varied along this same gradient from black chernozems (frigid hapludolls) at blocks 1 and 2, to brown chernozems (aridic haplustolls) at blocks 6, 8, and 9 (Agriculture Canada Expert Committee on Soil Survey 1987). Blocks were limited to level, uncultivated range sites typical of the landscape in which each block occurred. Treatments were assumed to be random in each block, since the relative orientation of grazed to ungrazed units varied with each pair. Adjacent treatments were also assumed to approximate a before-after, control-impact arrangement within each block.

Although grazing regime and range condition varied among blocks (Table 1), the objective of this investigation was to determine coarse scale responses of northern rangelands to long-term grazing exclusion. Selecting blocks with ungrazed exclosures 20 years old or greater and classified as "excellent" condition

\section{Vegetation and Soil Sampling}

In each experimental unit, 3 to 6 subsample points were established. Variation in this number was due to the extremely small size of some exclosures (Table 1). Subsamples were positioned 3 to $5 \mathrm{~m}$ from fence lines to avoid cattle trails and other edge effects, which limited the possible sampling area to a diameter of $4 \mathrm{~m}$ in the smallest exclosures. Thus only 3 points would fit within these smaller exclosures, and the adjacent grazed area (though $>100$ ha in size) was similarly sampled within a $4 \mathrm{~m}$ diameter area on the same range site. Where larger exclosures and range sites permitted, we increased the sampling intensity to 4 or 6 subsample points to better represent the larger units. In some of these cases the range site was large enough to spread out our sampling points within a $50 \mathrm{~m}$ diameter area (Fig. 1). As such, the sampling area and intensity varied among blocks but was kept consistent among treatments within each block.

At each subsample point, basal cover of vegetation, litter and bare ground were visually estimated within a $0.25 \mathrm{~m}^{2}$ square quadrat. Standing dead and surface litter were hand raked from within each quadrat until mineral soil was reached. The remaining live, rooted vegetation was clipped at ground level and removed. To each of these 2 above ground fractions, all dried and fresh cattle dung was added to the litter fraction and foliose lichens added to the vegetation fraction. Both dung and lichens contribute residues to the soil organic matter pool below, and were essential components of above ground carbon to include. The resulting vegetation and litter fractions were oven dried at $70^{\circ} \mathrm{C}$ for 48 hours prior to dry wt determination.

At each subsample point, 3 cylindrical soil cores $(6.7 \mathrm{~cm}$ diameter $\mathrm{x} 110 \mathrm{~cm}$ depth) were extracted using a truck mounted hydraulic corer. Coring positions within each clipped and raked quadrat were selected to proportionately represent the basal cover of plant crowns, cryptogams (mosses and lichens) and bare ground among the 3 cores. Large diameter cores allowed incorporation of this horizontal heterogeneity in each core, rather than stratified sampling of plant crowns and interspaces among multiple cores. The 3 cores removed from each quadrat were laid out side by side to select common depth increments based on natural horizons identified in the field (Agriculture Canada Expert Committee on Soil Survey 1987). Up to 10 depth increments were selected and the 3 cores from each quadrat were combined for each increment. Increments 
were as little as $5 \mathrm{~cm}$ thick, and no increment exceeded $15 \mathrm{~cm}$ in thickness, all to facilitate accurate calculation of organic carbon mass per equivalent soil mass. Field soil samples were stored in a cold room $\left(-0.5^{\circ} \mathrm{C}\right)$ up to 2 days before being processed in the lab (Bates 1993).

Bulk density was determined for each field soil sample by multiplying the wet sample mass per volume by an oven dried proportion; the latter determined from a 50 to $75 \mathrm{~g}$ subsample weighed wet and after drying at $110^{\circ} \mathrm{C}$ for 48 hours (Culley 1993). The remainder of each field soil sample was air dried for 1 week, prior to physical separation of up to 4 fractions. Plant crowns were separated from surface samples by hand picking. This fraction represented above ground portions (stem and leaf material) of vascular plants and little clubmoss (Selaginella densa Rydb.) that could not be removed by clipping. Macro-organic matter represented a combination of live and partially decomposed roots, litter, seeds, insect exuviae and other organic debris larger than $0.5 \mathrm{~mm}$ (Gregorich and Ellert 1993). Gravel and macro-organic matter $>2 \mathrm{~mm}$ were first separated by hand crushing each air dried soil sample and sieving through a $2 \mathrm{~mm}$ mesh. Additional macro-organic matter was separated from fine soil by 2 to 3 repetitions of hand crushing, sieving $(0.5 \mathrm{~mm}$ mesh) and winnowing. For winnowing a tabletop grain cleaner was used to separate heavy particles (fine soil) and light particles (macro-organic matter) between 0.5 and $2 \mathrm{~mm}$ in size. Soil that passed a 0.5 $\mathrm{mm}$ sieve was combined with heavy particles $(0.5$ to $2 \mathrm{~mm})$ from winnowing to comprise the fine soil fraction. The macroorganic matter was oven dried at $70^{\circ} \mathrm{C}$ for 48 hours and dry weight determined for calculation of dry mass.

\section{Carbon and Equivalent Soil Mass Determination}

Organic carbon content of all vegetation, litter, macro-organic matter and fine soil organic fractions was determined by dry combustion and gas chromatography in a Carlo-Erba NC2100 elemental analyzer (Pella 1990) located at the Agriculture and Agri-Food Canada Research Centre in Lethbridge, Alberta. Following fine ground preparation of vegetation, litter, macro-organic matter and fine soil organic samples to pass a $0.1 \mathrm{~mm}$ sieve, a 10 to 40 mg subsample was removed for carbon analyses. Due to the carbonate $\left(\mathrm{CO}_{3}{ }^{-2}\right)$ rich parent materials in which these soils developed, all fine soil organic subsamples were acidified with $6 \mathrm{M} \mathrm{HCl}$ to evolve inorganic $\mathrm{CO}_{3}^{-2}$ (Nelson and Sommers 1996). Acidified samples were oven dried at $70^{\circ} \mathrm{C}$ for 24 hours, which retained any soluble $\mathrm{C}$ compounds that might otherwise be lost by decanting the acid. The resulting organic fine soil organic carbon represents primarily those compounds derived from the ecosystem since deglaciation. Organic carbon mass ha ${ }^{-1}$ was calculated for vegetation, litter and plant crown fractions by simply multiplying carbon content with biomass ha ${ }^{-1}$ measurements. Fine soil organic carbon and macro-organic matter carbon mass ha ${ }^{-1}$ calculation required a more complex method.

Ellert and Bettany (1995) promote reporting soil elemental concentrations on an equivalent mass basis to provide a quantitative measure independent of treatment differences in bulk density. Fine soil organic carbon and macro-organic matter carbon mass values from original depth increments were adjusted by adding an additional organic carbon mass from a portion of the next deepest increment until an equivalent soil mass was achieved among all 74 subsamples within the 18 experimental units. Each of the 4 equivalent soil mass values selected $(1000,2000,4000$ and $8000 \mathrm{Mg} \mathrm{ha}^{-1}$ ) represents soil from the surface to successively greater depths; although soil layer thickness varied among experimental units for the same equivalent soil mass (Fig. 2). Analyses were restricted to samples above $80 \mathrm{~cm}$, because it was not always possible to sample to $110 \mathrm{~cm}$ depth in each experimental unit.

\section{Data Analyses}

Data for all carbon mass variables were skewed and heteroscedastic, so a nonparametric Wilcoxon Signed-Rank test was used to identify paired grazed vs. ungrazed treatment differences ( alpha $=0.05$ ). Paired analyses assume among block variation is greater than between treatments within a block. As such, the Wilcoxon Signed Rank test sums the proportional change between treatments in each block $(n=9)$ to test the null hypothesis that the sum of pair differences is equal to zero (Steel et al. 1997). The Wilcoxon Signed Rank tests were also conducted to evaluate whether the prediction soil sampling depth should be shallower under grazed (compacted) treatments to achieve a soil mass equivalent to the ungrazed treatments. This test was used to support the choice of equivalent mass as a superior reporting method.

Data from blocks 1 and 2 were the outliers that skewed each distribution. Removal of these 2 outliers from the foothill fescue prairie improved normality and made possible a more sensitive and robust parametric test for treatment differences. It was also possible these 2 foothill fescue prairie sites differed in response to grazing, relative to mixed prairie sites (Dormaar et al. 1977, Dormaar and Willms 1993). However, this reduced data set $(n=7)$ limited the scope of the gradient and the objective of this investigation. As such, to illustrate an intraregional gradient among blocks 3 to 9, yet still minimize among block variation to test for grazing treatment differences, ANCOVA was applied (Steel et al. 1997). Seven potential soil organic matter covariates (Parton et al. 1987) were assessed from elevation, climate and soil textural data for each site (Table 1). The only covariate significantly correlated $(\mathrm{P}<0.05)$ for all fine soil organic carbon variables was \% clay content of the soil. None of the environmental variables correlated with macroorganic matter carbon, and no further analyses were pursued for this variable.

\section{Results and Discussion}

\section{Equivalent Mass Determination}

Sampling depths to achieve equivalent masses of 1000 and $2000 \mathrm{Mg} \mathrm{ha}^{-1}$ were significantly deeper $(P<0.05)$ under grazing exclusion (Fig. 2). Bulk density increased on grazed areas in response to compaction by livestock. Differences in bulk density between blocks varying in soil texture and soil organic matter were apparent. Low bulk densities from blocks 1 and 2 may have been related to the large soil organic matter component (9 to $13 \%$ organic carbon) and clay content (32 to $36 \%$ ), and a greater volume of soil was required to achieve equivalent mass relative to other sites. High bulk densities from blocks 4 and 5 may have been related to the large sand content (55 to $82 \%$ ), and a smaller volume of soil was required to achieve equivalent mass.

Similar research often reports treatment differences in both bulk density and soil carbon mass per volume, but few researchers have reported soil carbon on an equivalent mass basis (Berg et al. 1997, Mikhailova et al. 2000). Although Berg et al. (1997) compared methods of reporting soil carbon, they still recommended mass per volume (referred to as "concentration") because it generated greater, though not statistically significant, differences between grazed and ungrazed treatments. Since livestock grazing can cause soil compaction, or conversely grazing exclu- 


\section{Block Number and Grazed (G) or Ungrazed (U)}

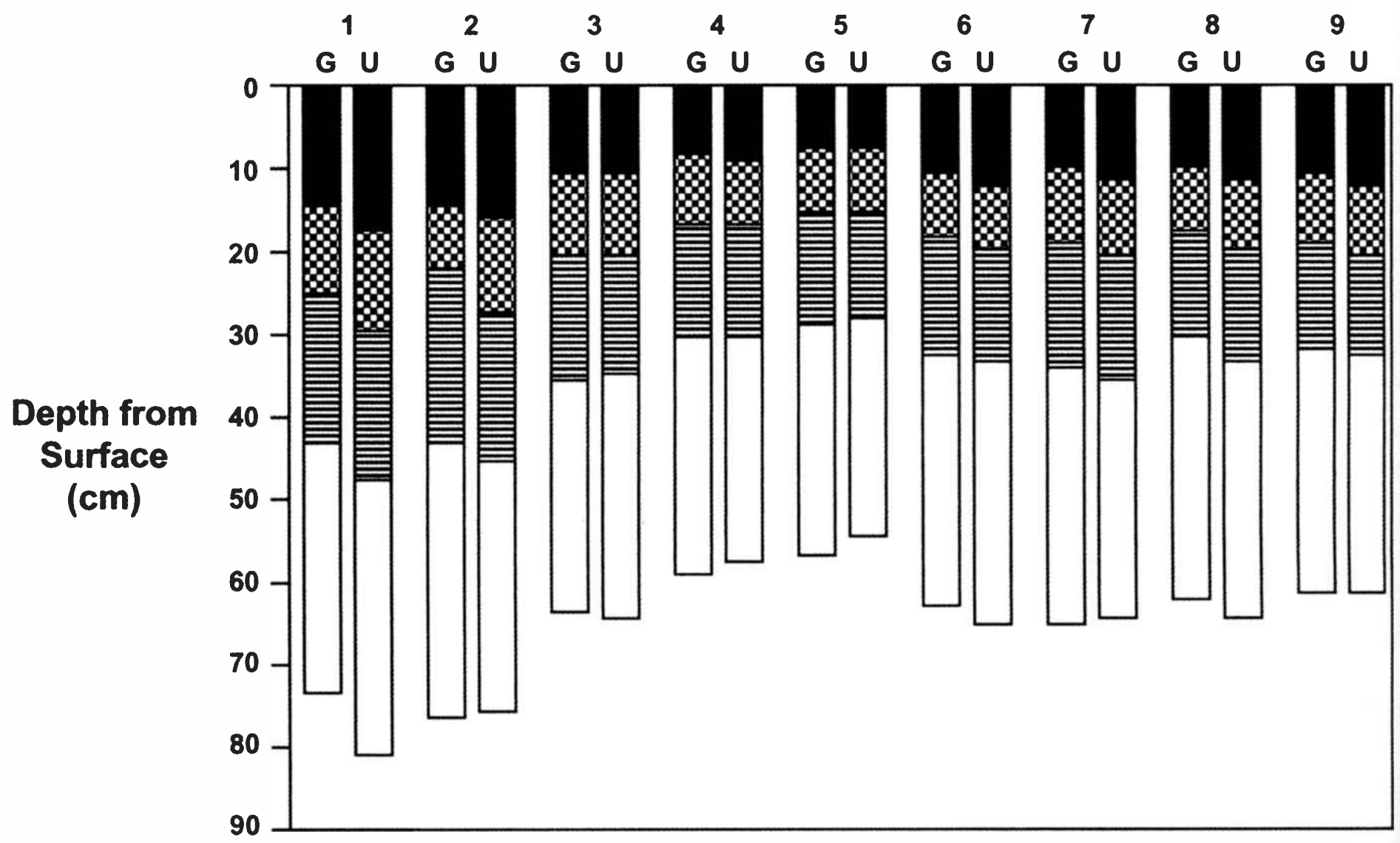

Layer thickness to $1000 \mathrm{Mg} \mathrm{ha}^{-1}$ Soil Additional layer to $2000 \mathrm{Mg} \mathrm{ha}^{-1}$ Soil
Additional layer to $4000 \mathrm{Mg} \mathrm{ha}^{-1}$ Soil Additional layer to $8000 \mathrm{Mg} \mathrm{ha}^{-1}$ Soil

Fig. 2. Sampling depths required to achieve 4 equivalent soil masses from long-term grazed and ungrazed grasslands at all 9 sites in southern Alberta, Canada. Significantly greater depths were required for ungrazed treatments to achieve 1000 and $2000 \mathrm{Mg}^{-1}$ soil $(\mathrm{P}<0.05$ Wilcoxon Signed-Rank Test).

sion can permit a loosening of soil through root growth and freeze-thaw, controlling for bulk density differences is essential. A compact, heavy sample of soil from the uppermost $10 \mathrm{~cm}$ of soil may contain more carbon by mass than a loose sample of soil from the same depth, even though both may have the same \% carbon. To draw the conclusion that grazing increases soil organic carbon would be incorrect, because there were no corrections for treatment differences in bulk density. Concentration by $\%$ or $\mathrm{g} \mathrm{kg}^{-1}$ is another approach to compare treatments and control for bulk density differences, but does not allow spatial scaling of results. A quantitative measure of soil mass per area is necessary for modeling landscape and regional responses of soil organic matter to grazing and grazing exclusion (Ellert and Bettany 1995).

\section{Above Ground Responses to Grazing}

Litter cover, and litter and vegetation carbon mass were both greater under grazing exclusion (Table 2). This response was expected, since defoliation by livestock should reduce live plant biomass and residue inputs to the litter pool (Milchunas and Lauenroth 1993). In the absence of livestock trampling plant root growth loosens soil, forms more macropores and increases infiltration (Naeth et al. 1990, Facelli and Pickett 1991). Litter moderates the soil microclimate such that shade lowers temperatures during summer and insulation lengthens the frost-free period during spring and fall. Litter also reduces evaporation and retains soil moisture (Knapp and Seastedt 1986, Willms et al. 1986, 1993, Facelli and Pickett 1991). Grazing exclusion altered patterns of litter accumulation and this change may have affected soil nutrient cycles and pool size (Holland and Coleman 1987, LeCain et al. 2000).

There was no difference among grazing treatments in basal area of cryptogams or vascular vegetation (grasses, forbs, and shrubs), nor was there a difference in plant crown carbon mass. Although there was a change in relative species composition (Moisey and Adams 1999, Henderson 2000), this was not reflected in the horizontal structure of grazed and ungrazed range types. However, species compositional change may have affected the vertical distribution of below ground biomass (Weaver 1950).

\section{Below Ground Responses to Grazing}

There was no difference among grazing treatments in macro-organic matter carbon mass for all 4 equivalent soil masses 
Table 2. Comparison of vegetation cover and organic carbon mass among long-term grazed and ungrazed grasslands at 9 sites in southern Alberta, Canada.

\begin{tabular}{lccc}
\hline \hline $\begin{array}{l}\text { Above Ground } \\
\text { Fraction }\end{array}$ & $\begin{array}{c}\text { Grazed } \\
\text { (Mean } \pm \text { SE) }\end{array}$ & $\begin{array}{c}\text { Ungrazed } \\
(\text { Mean } \pm \text { SE) }\end{array}$ & $\begin{array}{c}\text { Wilcoxon Signed } \\
\text { Rank (P) }\end{array}$ \\
\hline Bare Ground & \multicolumn{2}{c}{ Basal Cover (\%) } & \\
Litter & $12.7 \pm 2.8$ & $2.6 \pm 0.9$ & 0.011 \\
Cryptogams & $18.0 \pm 5.0$ & $35.6 \pm 6.1$ & 0.011 \\
Vascular Plants & $20.8 \pm 6.7$ & $13.7 \pm 5.2$ & 0.086 \\
& $48.5 \pm 3.6$ & $48.0 \pm 3.4$ & 0.953 \\
Plant Crowns & Organic Carbon $\left(\mathrm{Mg} \mathrm{ha}^{-1}\right)$ & \\
Litter & $1.37 \pm 0.21$ & 0.515 \\
Vegetation & $0.62 \pm 0.20$ & $1.70 \pm 0.32$ & 0.008 \\
\hline & $0.71 \pm 0.14$ & $1.79 \pm 0.60$ & 0.050 \\
\hline
\end{tabular}

(Table 3). Dormaar and Willms (1998) suggested the shift in species composition with grazing leads to both horizontal and vertical changes in plant community architecture. In fescue prairie, grazing should decrease the cover of rough fescue and overall root biomass. A smaller root mass should contribute less organic residue to the soil and macro-organic matter carbon mass should decrease. In contrast, several researchers suggest a direct and dependent relationship between an increase in soil carbon with grazing and an increase in blue grama (Bouteloua gracilis $\mathrm{HBK}$ ) cover on mixed grass prairie. This species reportedly leads to increased residue inputs and thus soil carbon (Dormaar and Willms 1990, 1993, Derner et al. 1997, Kelly and Burke 1997). While localized effects under individual plants may occur, at the larger scale our data do not support these earlier findings; because, there was no difference among treatments for macroorganic matter carbon despite a change in blue grama cover (Moisey and Adams 1999, Henderson 2000).

No significant difference occurred in fine soil organic carbon mass for all 4 equivalent soil masses (Fig. 3). The response of northern rangeland soils to grazing or grazing exclusion may be unique to each independent location, and this may account for the high variability and lack of a general trend. Replication at the landscape scale, instead of the region as in this study, would be necessary to detect landscape scale differences. In that case, a sample size of 7 to 9 may be insufficient for detecting regional scale differences (if, in fact, a single pattern exists). Alternatively, treatments separated spatially may have differed prior to grazing exclusion and the assumption of adjacent sites approximating a BACI design is unwise. Alberta, Canada.

\section{Differential Responses Along A Gradient}

Mean annual precipitation and \% clay content were positively correlated with both macro-organic matter carbon and fine soil organic carbon mass at all 4 equivalent masses $(P<0.05, n=9)$. Sims and Nielsen (1986) found the same 2 environmental variables were correlated with soil organic matter along a similar gradient immediately south in Montana. Blocks 1 and 2 were consistent outliers in and biased interpretation of correlation analyses, since both blocks were nearly twice the fine soil organic carbon and macroorganic matter carbon mass of all other blocks. Removal of these 2 blocks resulted in \% clay content as the only significant correlate $(\mathrm{P}<0.05, \mathrm{n}=7)$ and only with fine soil organic carbon mass. The 7 remaining sites were all semiarid, mixed grass prairie. Sims et al. (1978) and Sala et al. (1988) identified 370 to $400 \mathrm{~mm}$ mean annual precipitation as the point at which a transition in above ground ecosystem responses to grazing occurs in the northern Great Plains, which may confer a differential below ground response. By removing the 2 subhumid blocks ( $>400 \mathrm{~mm}$ mean annual precipitation) this differential response among ecoregions could not be analyzed, although it was possible to test for grazing treatment effects along a soil texture gradient within the mixed grass prairie ecoregion alone. There were no significant differences in fine soil organic carbon mass intercepts at all 4 equivalent soil masses with \% clay content as the covariate (Fig. 2).

Reports of no change or increases in soil organic carbon with grazing come from experiments with replicates restricted to 1 mixed grass prairie landscape. Following 7 years of experimental grazing in North Dakota, Biondini et al. (1998) reported no difference in soil organic carbon mass per volume within the top $10 \mathrm{~cm}$ of soil. Naeth et al. (1991) reported a similar observation for a mixed grass prairie site in southern Alberta. In Wyoming, both Manley et al. (1995) and Schuman et al. (1999) found soil organic carbon was up to $10 \mathrm{Mg} \mathrm{ha}^{-1}$ greater in the near surface soil under the same grazed treatments after 11 to 12 years. Dormaar and Willms (1990) and Dormaar et al. (1994) observed a similar pattern for 2 Alberta mixed prairie sites.

In cases where replication beyond a single landscape has been attempted, increases in soil organic carbon tend to be associated with grazing exclusion. Stohlgren et al. (1999) compared 3 separate pasture and exclosure pairs (13 to 31 years since exclusion) in Montana mixed grass prairie, and surface soils under exclosures had consistently greater \% carbon than adjacent grazed areas. Bauer et al. (1987) found a similar pattern in carbon mass per volume after comparing 12 grazed and 12 ungrazed, independent mixed grass prairie sites in North Dakota, representing a variety of soil textural groups. In that study, the magnitude of grazing treatment differences was greater for sandy textured soils than loam and clay. Duration of grazing or grazing exclusion was unknown, but at

Table 3. Comparison of fine soil organic carbon and macro-organic matter carbon mass at 4 equivalent soil masses among long-term grazed and ungrazed grasslands at 9 sites in southern

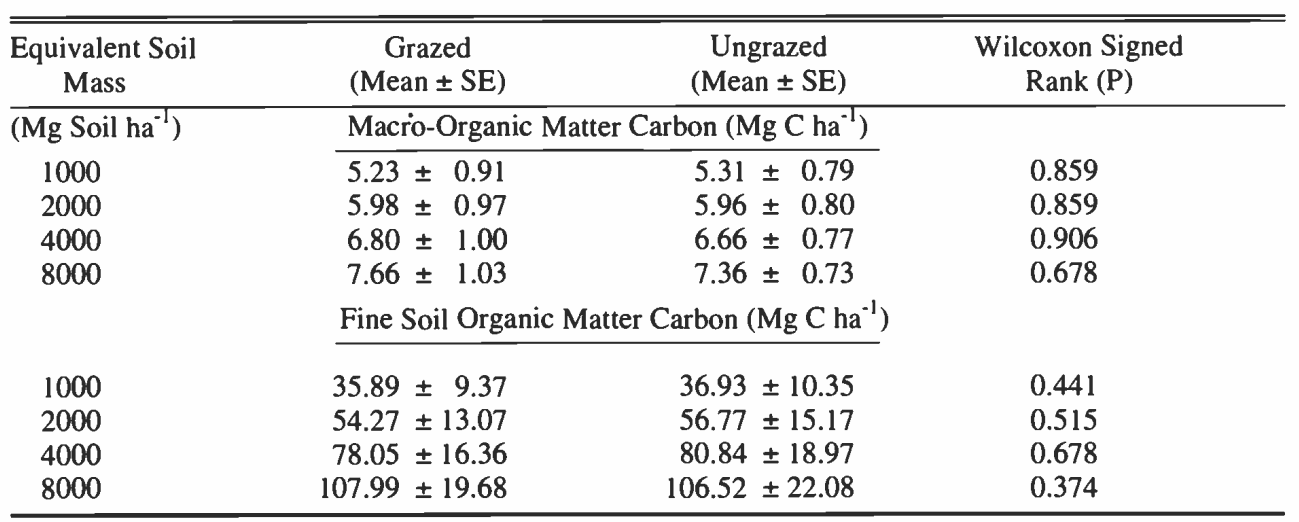




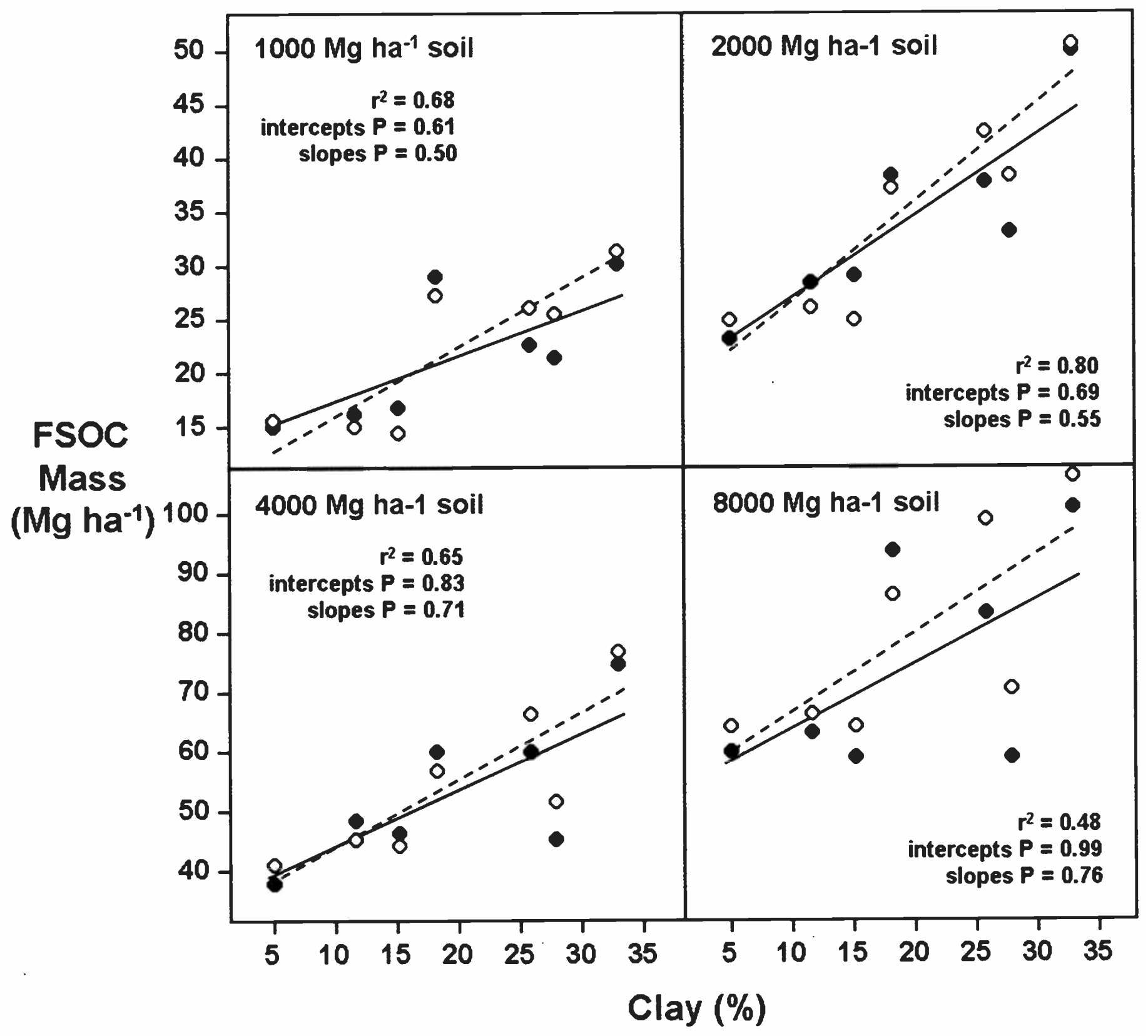

Fig. 3. Analysis of covariance for fine soil organic carbon (FSOC) mass at 4 equivalent soil masses among paired grazed and ungrazed grasslands at 7 mixed-grass prairie sites in southern Alberta, Canada. Open circles with the dashed trend line are grazed and black circles with the solid trend line are ungrazed.

least 75 years. Frank et al. (1995) and Wienhold et al. (2001) reported a similar pattern in \% carbon for the same North Dakota site sampled after 75 and 80 years of consistent treatment application. Stocking rates and grazing regimes differed among independent locations in all previous research, and no single study has adequately replicated grazing systems or exclusion durations, further complicating interpretation.

Assumptions that predictable differences in above ground range type and production among grazed and ungrazed treatments contribute to predictable differences in below ground soil organic matter have not been supported in the literature or by this research. Much of the soil organic matter in temperate Canadian grasslands is an ancient product of vegetation, climate and soil development over 10,000 years since deglaciation, or even older inert lignite coal ground in the glacial till parent material (Anderson 1995, Seastedt 1995). Current estimates of organic carbon turnover rates for uncultivated, cold and dry grasslands suggest a significant change in the soil carbon pool may require centuries to millennia (Anderson and Paul 1984, Paul et al. 1997). In addition, continuous grazing by large ungulates on the northern Great Plains has been the norm for at least 8,000 years (Wells 1970, Axelrod 1985), and the ecosystem is likely in equilibrium under continuous grazing. Short-term modification of the grazing regime may have less impact than complete grazing exclusion on an organic carbon pool subjected to grazing for millennia; yet no consistent grazing exclusion response has emerged from this investigation or others.

\section{Conclusions}

No consistent response of soil organic carbon mass to grazing was demonstrated.

Treatment differences were small (less than $5 \%$ of total soil organic carbon mass) 
and not statistically significant. Including the large and heterogeneous background mass of old organic carbon at depth may complicate detection of short-term treatment responses. However, there were no differences in more labile residues (macroorganic matter carbon) at shallower depths (1000 $\mathrm{Mg} \mathrm{ha}^{-1}$ soil). Inconsistent treatment responses among blocks may indicate grazing impacts are related to a combination of site factors and difficult to generalize, even within an ecoregion.

Current range management in the northern Great Plains aims to optimize forage production through litter carryover for soil moisture conservation (Wroe et al. 1988, Willms and Jefferson 1993), and this appears to be consistent with maintaining the soil organic carbon pool. Definitive answers lay in a combination of similarly controlled experimental sites, with replicated grazing regimes, that use a single sampling and reporting protocol. Coordination amongst researchers in the design, execution and analysis of longterm grazing experiments will yield both accurate and precise data for meta-analysis and regional models of grazing impacts on ecosystem processes and patterns. Such coordination is necessary to provide data sets useful for developing general theory on the ecological impacts of grazing, and management prescriptions for carbon sequestration.

\section{Literature Cited}

Agriculture Canada Expert Committee on Soil Survey. 1987. The Canadian system of soil classification. Second edition. Agriculture Canada Expert Committee on Soil Survey, Agriculture Canada Publication 1646, Ottawa, Ont.

AGRASID. 1998. Agricultural region of Alberta soil inventory database. Version 1.0. Alberta Agriculture, Food and Rural Development, Edmonton, Alb.

Allen-Diaz, B. 1996. Rangelands in a changing climate: Impacts, adaptations and mitigation, p. 133-158. In: R.T. Watson, M.C. Zinyowera, R.H. Moss and D.J. Dokken (eds.) Climate change 1995: Impacts, adaptations and mitigation of climate change - scientific / technical analyses. Cambridge University Press, New York, N.Y.

Anderson, D.W. 1995. Decomposition of organic matter and carbon emissions from soils, p. 165-175. In: R. Lal, J. Kimble, E. Levine and B.A. Stewart (eds.) Soils and global change. Advances in soil science series. CRC Press Inc., Boca Raton, Fla.

Anderson, D.W. and E.A. Paul. 1984. Organo-mineral complexes and their study by radiocarbon dating. Soil Sci. Soc. Amer. J. 48:298-301.
Axelrod, D.I. 1985. Rise of the grassland biome, central North America. Biol. Rev. 51:163-201.

Bates, T.E. 1993. Soil handling and preparation. Chapter 3, p. 19-24. In: M.R. Carter (ed) Soil sampling and methods of analysis. Lewis Publishers, Boca Raton, Fla.

Bauer, A., C.V. Cole, and A.L. Black. 1987. Soil property comparisons in virgin grasslands between grazed and nongrazed management systems. Soil Sci. Soc. Amer. J. 51:176-182.

Berg, W.A., J.A. Bradford, and P.L. Sims. 1997. Long-term soil nitrogen and vegetation change on sandhill rangeland. J. Range Manage. 50:482-488.

Biondini, M.E., B.D. Patton, and P.E. Nyren. 1998. Grazing intensity and ecosystem processes in a northern mixed grass prairie, USA. Ecol. Appl. 8:469-479.

Brown, M.A. and S.S. Waller. 1986. The impact of experimental design on the application of grazing research results - an exposition. J. Range Manage. 39:197-200.

Bruce, J.P., M. Frome, E. Haites, H.H. Janzen, R. Lal, and K. Paustrian. 1999. Carbon sequestration in soils. J. Soil Water Conserv. 54:382-389.

Coupland, R.T. 1950. Ecology of mixed prairie in Canada. Ecol. Monogr. 20:271-315.

Culley, J.L.B. 1993. Density and compressibility. Chapter 50, p. 529-539. In: M.R. Carter (ed.) Soil sampling and methods of analysis. Lewis Publishers, Boca Raton, Fla.

Derner, J.D., D.D. Briske, and T.W. Boutton. 1997. Does grazing mediate soil carbon and nitrogen accumulation beneath C4 perennial grasses along an environmental gradient? Plant Soil 191:147-156.

Dormaar, J.F. and W.D. Willms. 1990. Effect of grazing and cultivation on some chemical properties of soils in the mixed prairie. $\mathrm{J}$. Range Manage. 43:456-460.

Dormaar, J.F. and W.D. Willms. 1993. Decomposition of blue grama and rough fescue roots in prairie soils. J. Range Manage. 46:207-213.

Dormaar, J.F. and W.D. Willms. 1998. Effect of forty-four years of grazing on fescue grassland soils. J. Range Manage. 51:122-126.

Dormaar, J.F., B.W. Adams, and W.D. Willms. 1994. Effect of grazing and abandoned cultivation on a Stipa-Bouteloua community. J. Range Manage. 47:28-32.

Dormaar, J.F., A. Johnston, and S. Smoliak. 1977. Seasonal variation in chemical characteristics of soil organic matter of grazed and ungrazed mixed prairie and fescue grassland. J. Range Manage. 30:195-198.

Dormaar, J.F., S. Smoliak, and W.D. Willms. 1989. Vegetation and soil responses to short-duration grazing on fescue grasslands. J. Range Manage. 42:252-256.

Ellert, B.H. and J.R. Bettany. 1995. Calculation of organic matter and nutrients stored in soils under contrasting management regimes. Can. J. Soil Sci. 75:529-538.
Environment Canada. 1996. Canadian climate normals 1961-1990. Alberta. Environment Canada, Atmospheric Environment Service, Ottawa, Ont.

Eswaran, H., P. VandenBerg, and J. Kimble. 1995. Global soil carbon resources, p. 27-43. In: R. Lal, J. Kimble, E. Levine and B.A. Stewart (eds.) Soils and global change. Advances in soil science series. CRC Press Inc., Boca Raton, Fla.

Facelli, J.M. and S.T.A. Pickett. 1991. Plant litter: Its dynamics and effects on plant community structure. Bot. Rev. 57:1-32.

Frank, A.B., D.L. Tanaka, L. Hoffman, and R.F. Follet. 1995. Soil carbon and nitrogen of northern Great Plains grasslands as influenced by long-term grazing. J. Range Manage. 48:470-474.

Gregorich, E.G. and B.H. Ellert. 1993. Light fraction and macroorganic matter in mineral soils. Chapter 39, p. 397-407. In: M.R. Carter (ed.) Soil sampling and methods of analysis. Lewis Publishers, Boca Raton, Fla.

Henderson, D.C. 2000. Carbon storage in grazed prairie grasslands of Alberta. M.Sc. thesis, Department of Renewable Resources, University of Alberta, Edmonton, Alb.

Holechek, J.L., R.D. Pieper, and C.H. Herbel. 1998. Range management principles and practices. 3rd ed. Prentice Hall, Upper Saddle River, N.J..

Holland, E.A. and D.C. Coleman. 1987. Litter placement effects on microbial and organic matter dynamics in an agroecosystem. Ecol. 68:425-433.

Kelly, R.H. and I.C. Burke. 1997. Heterogeneity of soil organic matter following death of individual plants in shortgrass steppe. Ecol. 78:1256-1261.

Knapp, A.K. and T.R. Seastedt. 1986. Detritus accumulation limits productivity of tallgrass prairie. Biosc.i 6:662-668.

Lal, R., J. Kimble, and B.A. Stewart. 1995. World soils as a source or sink for radioactively active gases, p. 1-7. In: R. Lal, J. Kimble, E. Levine and B.A. Stewart (eds.) Soil management and the greenhouse effect. Advances in soil science series. CRC Press Inc., Boca Raton, Fla.

LeCain, D.R., J.A. Morgan, G.E. Schuman, J.D. Reeder, and R.H. Hart. 2000. Carbon exchange rates in grazed and ungrazed pastures of Wyoming. J. Range Manage. 53:199-206.

Manley, J.T., G.E. Schuman, J.D. Reeder, and R.H. Hunt. 1995. Rangeland soil carbon and nitrogen responses to grazing. J. Soil Water Conserv.294-298.

Mikhailova, E.A., R.B. Bryant, D.J.R. Cherney, C.H. Post, and I.I. Vassenev. 2000. Botanical composition, soil and forage quality under different management regimes in Russian grasslands. Agr. Ecosyst. Environ. 80:213-226.

Milchunas, D.G. and W.K. Lauenroth. 1993. Quantitative effects of grazing on vegetation and soils over a global range of environments. Ecol. Monogr. 63:327-366. 
Milchunas, D.G., O.E. Sala, and W.K. Lauenroth. 1988. A generalized model of the effects of grazing by large herbivores on grassland community structure. Amer. Nat. 132:87-106.

Moisey, D. and B.W. Adams. 1999. Annual summary-rangeland benchmark network monitoring program within the grassland natural region. Unpublished report. Alberta Agr., Food and Rural Deve. - Public Lands Division, Lethbridge, Alb.

Moss, E.H. and J.A. Campbell. 1947. The fescue grassland association of Alberta. Can. J. Res. 25:209-227.

Naeth, M.A., A.W. Bailey, D.J. Pluth, D.S. Chanasyk, and R.T. Hardin. 1991. Grazing impacts on litter and soil organic matter in mixed prairie and fescue prairie ecosystems of Alberta. J. Range Manage. 44:7-12.

Naeth, M.A., D.J. Pluth, D.S. Chanasyk, A.W. Bailey, and A.W. Fedkenheuer. 1990. Soil compacting impacts of grazing in mixed prairie and fescue grassland ecosystems of Alberta. Can. J. Soil Sci. 70:157-167.

Nelson, D.W. and L.E. Sommers. 1996. Total carbon, organic carbon, and organic matter. Chapter 34, p. 961-1010. In: A. Klute (ed) Methods of soil analysis. Part 3. Chemical methods. Soil Sci. Soc. Amer. Book series no. 5, Madison, Wis.

Oksanen, L. 2001. Logic of experiments in ecology: Is pseudoreplication a pseudoissue? Oikos 94:27-38.

Osenberg, C.W., O. Sarnelle, S.D. Cooper, and R.D. Holt. 1999. Resolving ecological questions through meta-analysis: Goals, metrics, and models. Ecology 80:1105-1117.

Parton, W.J., D.S. Schimel, C.V. Cole, and D.S. Ojima. 1987. Analysis of factors controlling soil organic matter levels in Great Plains grasslands. Soil Sci. Soc. Amer. J. 51:1173-1179.
Paul, E.A., R.F. Follet, S.W. Leavitt, A. Halvorson, G.A. Peterson, and D.J. Lyon. 1997. Radiocarbon dating for determination of soil organic matter pool sizes and dynamics. Soil Sci. Soc. Amer. J. 61:1058-1067.

Pella, E. 1990. Elemental organic analysis. Part 2: State of the art. Am. Lab. 22:28-32.

Sala, O.E., W.J. Parton, L.A. Joyce, and W.K. Lauenroth. 1988. Primary production of the central grassland region of the United States. Ecol. 69:40-45.

Schuman, G.E., J.D. Reeder, J.T. Manley, R.H. Hart, and W.A. Manley. 1999. Impact of grazing management on the carbon and nitrogen balance of a mixed grass rangeland. Ecol. Appl. 9:65-71.

Seastedt, T.R. 1995. Soil systems and nutrient cycles of the North American prairie, p. 157-174. In: A. Joern, and K.H. Keeler (eds.) The changing prairie: North American grasslands. Oxford University Press, New York, N.Y.

Sims, P.L., J.S. Singh, and W.K. Lauenroth. 1978. The structure and function of ten western North American grasslands. 1. Abiotic and vegetational characteristics. J. Ecol. $66: 251-285$.

Sims, Z.R. and G.A. Nielsen. 1986. Organic carbon in Montana soils as related to clay content and climate. Soil Sci. Soc. Am. J. 50:1269-1271.

Steel, R.G.D., J.H. Torrie, and D.A. Dickey. 1997. Principles and procedures of statistics: A biometrical approach. 3rd ed. WCB McGraw-Hill, New York, N.Y.

Stohlgren, T.J., LD. Schell, and B. Vanden Heuvel. 1999. How grazing and soil quality affect native and exotic plant diversity in Rocky Mountain grasslands. Ecol. Appl. 9:45-64.
Strong, W.L. and K.R. Leggat. 1991. Ecoregions of Alberta. Second edition. Alberta Forestry, Lands and Wildlife, Land Information Services, Edmonton, Alb.

Stroup, W.W., S.S. Waller, and R.N. Gates. 1986. Exposition on the selection of appropriate experimental design and statistical analysis for pasture improvement research. J. Range Manage. 39:200-207.

Weaver, J.E. 1950. Effects of different intensities of grazing in depth and quantity of roots of grasses. J. Range Manage. 3:100-113.

Wells, P.V. 1970. Postglacial vegetational history of the Great Plains. Science 167:1574-1582.

Wienhold, B.J., J.R. Hendrickson, and J.F. Karn. 2001. Pasture management influences on soil properties in the northern Great Plains. J. Soil Water Conserve. 56:27-31.

Willms, W.D. and P.G. Jefferson. 1993. Production characteristics of the mixed prairie: Constraints and potential. Can. J. Anim. Sci. 73:765-778.

Willms, W.D., S.M. McGinn, and J.F. Dormaar. 1993. Influence of litter on herbage production in the mixed prairie. J. Range Manage. 46:320-324.

Willms, W.D., S. Smoliak, and A.W. Bailey. 1986. Herbage production following litter removal on Alberta native grasslands. J. Range Manage. 39:536-540.

Wroe, R.A., S. Smoliak, B.W. Adams, W.D. Willms, and M.L. Anderson. 1988. Guide to range condition and stocking rates for Alberta grasslands 1988. Alberta Forestry, Lands and Wildl.. Public Lands, Edmonton, Alb. 